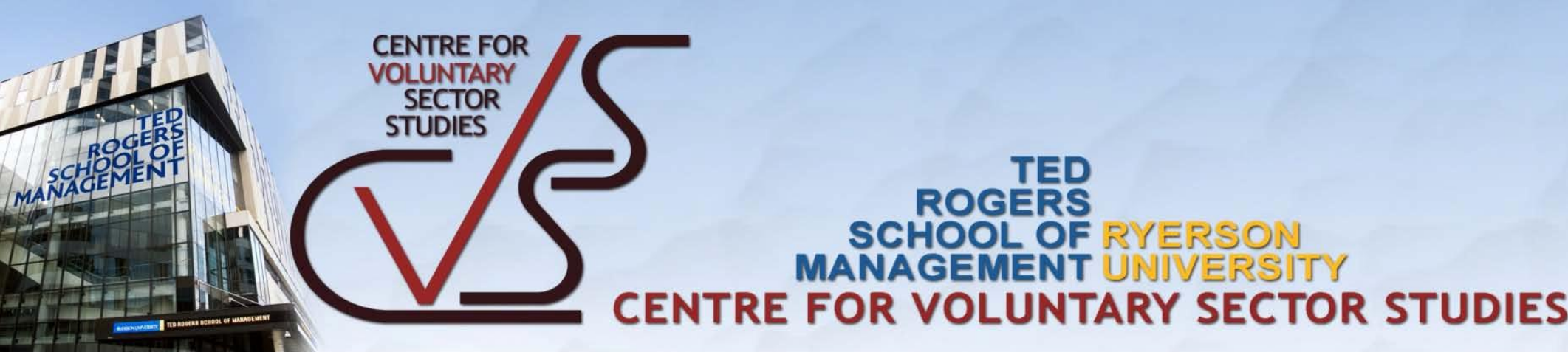

\title{
Structuring Student Volunteering Programs to the Benefit of Students and the Community: The Ontario Experience
}

\author{
Mary Foster and Agnes Meinhard ${ }^{1}$ \\ Centre for Voluntary Sector Studies, Ryerson University
}

\begin{abstract}
* Note to the reader: This paper is a continuation of the analysis reported in Working Paper Volume 1999 (1). The background section of this paper is similar to the other, but the results reported are new.
\end{abstract}

\author{
Working Paper Series \\ Volume 2000 (2)
}

\author{
350 Victoria Street \\ Toronto, Ontario M5B 2K3 \\ Tel: 416-979-5146 x 6739 / Fax: 416-979-5124 \\ cvss@ryerson.ca \\ http://www.ryerson.ca/cvss/working_papers
}

\footnotetext{
${ }^{1}$ This research was supported by an institutional grant from the Social Sciences and Humanities Research Council. This paper is dedicated to the memory of Chantal Hall Skinner, whose tireless efforts in contacting schools enabled us to get an accurate estimate of scope of community service programs in Toronto's High Schools. Many thanks to Grace McDonald, who organized our sample and questionnaire distribution and to Keith Duncanson and John Kapala, who helped in data collection and analysis. Special thanks to the high school principals and teachers who allowed us to survey their students, and to all the student volunteers.
} 


\section{Introduction}

One of the many challenges facing the nonprofit sector in Canada today is developing public awareness of the important role of voluntary organizations in the everyday lives of Canadians. Ranging from food banks, children's aid societies, and immigrant service organizations, to opera companies and sporting societies, nonprofit and voluntary organizations perform important functions in society.

First, they offer a startlingly wide array of services which cannot be adequately provided directly through the open marketplace or the state. The sector fills in gaps in the social safety net by providing services that were the traditional responsibility of the government. In addition, these organizations are seen as a significant vehicle for voluntary action, as illustrated by the sector's continuing growth. The number of organizations registering as charities at Revenue Canada has increased by 3 percent each year since 1987. During the same period there has been a $17 \%$ increase in the number of Canadians volunteering (Hall \& Banting, 2000). Finally, some believe as Putnam does that the voluntary sector contributes to social capital by increasing a society's ability to act collectively. This skill is important for financial performance and success in a global knowledge-based economy (Putnam, 1993, 1995).

Few Canadians are aware of the size of the sector or its contribution to the economy. As of June 1999, there are approximately 200,000 nonprofit organizations in Canada, 78,000 of which are registered charities. Almost one-third of Canadians volunteer, contributing the equivalent of 578,000 full-time jobs. This sector also accounts for $13 \%$ of GDP by employing $9 \%$ of the Canadian labour force (Hall \& Banting, 2000).

In the past five years in Ontario, the third sector has been experiencing radical changes as a result of government retrenchment. Whereas during the post-war decades there was close cooperation between governments and the voluntary sector, with many government programs encouraging the growth of the sector through the provision of grants, today the government is forcing the sector to seek its funding elsewhere. This has resulted in a significant increase in fundraising activities by voluntary organizations, whose success depends on the willingness of people to volunteer to help raise funds and to donate money.

This fiscal challenge is amplified by the fact that the nonprofit sector lacks the visibility and public awareness commonly accorded the private and government sectors (Salamon \& Anheier, 1996). Canadians, used to easy, and for the most part free, access to government provided or government supported social services, are mostly unaware of the fact that a large portion of these services was provided by nonprofit organizations. Education about the contribution of the voluntary sector to the quality of life that Canadians enjoy is the primary tool to increase awareness. Without education, "the ethos of giving will fail to develop, regardless of changes in tax and other laws" (Salamon \& Anheier, 1996:126). To be effective, education must start early, and the school provides one structure within which familiarity with the voluntary sector can be fostered.

This paper presents the results from a comprehensive survey conducted on a sample of 389 students (260

involved in community service programs and 129 controls) from ten high schools in the Greater Toronto Area. 


\section{Review of Literature}

\section{The Changing Face of Volunteer Activity}

Historically, in North America and in Britain, volunteer behaviour - the active participation in helping the poor and the needy, as opposed to merely the giving of alms - was initiated and encouraged by religious institutions and formed the foundation of the social welfare services (de Schweinitz, 1943; Feingold, 1987). By the beginning of the twentieth century, helping the poor became more secularized and professionalized as social workers gradually replaced religious volunteers and congregational voluntary action declined (Cnaan, Kasternakis \& Wineburg, 1993). The state formed a partnership with NPOs to provide the essential social services and volunteers were seen as adjuncts to the professionals. In Canada, during the halcyon postwar years governments encouraged the formation of nonprofit social service organizations providing professional care. They were to be part of an elaborate social welfare system, allies of the state, extending specialized services that the government was uninterested in or unable to provide. Not only did these organizations receive generous funding from government sources, but more importantly they also gained legitimacy to represent and serve their various constituencies (Tucker, Singh \& Meinhard, 1990). However in the current political and philosophical climate of cutbacks and downloading, nonprofit organizations are in crisis, having to cut services and staff in order to survive (Foster \& Meinhard, 1996; Meinhard \& Foster, 1997). The contribution of volunteers is once again sought after and valued. Premier Mike Harris of Ontario, won a landslide victory on a platform that identified reliance on personal volunteering as part of his government's strategic reallocation of services in the framework of the "Common Sense Revolution".

There is strong opposition to this emerging social philosophy. Both individuals and organizations, citing the high turnover rate and the subsequent high cost of constantly training volunteers, have presented the government with potent arguments against the devolution of social services from professionals to volunteers (e.g., Lefebvre, 1996). Nevertheless, the reality is that government funding for social and cultural services has decreased substantially in the last few years (Hall \& Banting, 2000). This has resulted in an attempt by social service organizations to avert cutting services by relying more on volunteers, either for help in providing services, or for fundraising purposes, where possible (Meinhard \& Foster, 1997). Given the situation, these organizations may benefit from a larger and better educated pool of volunteers.

\section{Community Service Programs}

Socializing children (and members of society as a whole) to the importance of community involvement and charitable giving is a key factor in this new social philosophy. This has traditionally been a role of religious institutions, as service to others and the obligation to helping the poor is central to all religious teaching (Feingold, 1987). Indeed, surveys of the determinants of voluntary action among teens have consistently pointed to the importance of parental example and religious affiliation as two of the strongest factors in predicting volunteer participation. Teens, whose parents are volunteers and who are affiliated with organized religion in some form, are more likely to participate in volunteer activities (Hodgkinson \& Weitzman, 1996). 
In an increasingly secularized society, it is unrealistic to rely solely on religious institutions to socialize societal members to community involvement and social action. As a matter of fact, Wuthnow (1991) found that religious institutions' primary goals are to encourage members first and foremost to volunteer for the benefit of the congregation. This does not necessarily translate into increased volunteer activity for the general good. Cnaan and his associates (1993), in a thorough review of studies investigating the relationship between religious beliefs and volunteering found the evidence for a relationship inconclusive. In their own study, they found no relationship between intrinsic religious motivation and volunteer activity concluding that other factors may be important in determining volunteering.

These findings, of course, do not negate a role for religious institutions in encouraging and educating their members to have greater community commitment. However, they do indicate that in order to instill voluntary community commitment and involvement in our young people, other sources of socialization are needed. The three pillars of socialization in North America are home, school and religious institution. All three of these were found to have an influence on the volunteering behaviour of teenagers (Sundeen \& Raskoff, 1994; Raskoff \& Sundeen, 1998). A survey of American teenagers by Prudential (1995) attested to the importance of schools, parents and role models in motivating student interest in community service.

In the United States, the concept of service learning or community service in the schools dates back to the turn of the century to the writings of John Dewey who pointed to the "importance of social and not just intellectual development; and the value of actions directed towards the welfare of others" (Kraft, 1986:133). Service learning has been approached with renewed vigour in American schools in the past two decades. It is seen as an antidote to the decline in communal and civic participation witnessed over that past half century, as individualism has prevailed over community in the constant American struggle to balance the two (Barber, 1992; Bellah et al., 1985; Putnam, 1995).

A 1986 survey of 5,400 high schools found that $27 \%$ of them had some form of community service program (Newman \& Rutter, 1986). Similarly a 1990 survey of volunteering by teenagers estimated that about one quarter of American high schools offered courses which included a component of volunteering for community service (Independent Sector, 1990; Sundeen \& Raskoff, 1994). In contrast to these findings, in Los Angeles County, $82 \%$ of schools, both public and private, have community service programs (Raskoff \& Sundeen, 1998).

\section{Benefits of Community Service Programs}

Theoretical models of service learning suggest "that community service may promote competence and self-esteem, reduce levels of problem behaviours, provide greater knowledge of community problems and advance cognitive and moral development in adolescents" (Moore \& Allen, 1996:224) In their detailed review of 8 different surveys of community service programs at both the high school and university levels, Moore and Allen (1996:242) concluded that volunteering through school programs reduced failure and dropout rates, improved reading skills, self-concept and attitudes towards society. However, participation in these programs did not relate to "increases in social competence, career exploration, greater problem solving abilities, responsibility towards school, anticipated participation in politics or beliefs in the individual's responsibility to help people in need." 
Kraft (1996:143) also reviewed evaluative studies of service learning programs. He concluded that there is "a lack of solid evidence on the effects of these programs" because it is "difficult to isolate the effects of service on specific academic achievements." He categorized the effects of service learning programs into five areas of impact:

a) social growth - the findings are mixed, some evidence that students become more service oriented, less prejudiced, more democratic, greater sense of social responsibility

b) psychological development - there is evidence that service learning programs have a positive effect on the development of a positive self-image, increased self-confidence and self-esteem.

c) moral judgment - the results are mixed, but there is some evidence of impact on moral judgment

d) academic learning - again there are mixed results. In general tests of knowledge there is usually no difference between service learners and the control groups, but on measures of reading and math achievement scores of tutors, there is improvement.

e) community served - there is evidence that young people have a positive impact on the community.

Presently, in the United States, there is a major federally funded effort underway called "Learn and Serve America School and Community-Based Programs". The program was established in 1993 with the objective of involving "school aged youth in programs and classroom activities that link meaningful service in the community with a structured learning experience" (Melchior, 1997:1). "Service-learning stands in contrast to traditional voluntarism... (in that it includes)... reflection and links to organized curriculum" (Melchoir, 1997:11).

Approximately $\$ 30$ million in grants were awarded in the first year of the program to support 2000 local efforts involving more than 750,000 school-aged youth. The Center for Human Resources at Brandeis University is conducting a long-term evaluation of the impact of the program. In their initial article, they reported statistically significant impacts on measures of personal and social responsibility, acceptance of cultural diversity and service leadership, with program participants scoring higher on all of these measures than nonparticipants. Program participants also volunteered their services more frequently and for longer hours. Interestingly the grade point averages, as well as other educational measures, showed greater improvement for participants than for nonparticipants (Melchior, 1997).

\section{Community Service in Canada}

The tension between individual pursuit of happiness and the good of the community that many scholars have remarked upon in the United States (Barber, 1992; Bellah et al., 1985, Putnam, 1995), is not a characteristic feature of Canada. As opposed to every individual's right to "Life, Liberty and the Pursuit of Happiness," as stated in the Declaration of Independence, the preamble of Canada's Constitution Act, 1867, talks of "Peace, Order and Good Government". It wasn't until the patriation of the constitution in 1982, that Canada had a written Charter of Rights outlining individual rights and obligations. For many historical reasons, in Canada, the common good generally took precedence over individual rights. In the struggle to keep the wide expanse of Canada together, the Canadian government has always been more involved in the management of both the economy and the welfare of its citizens. Thus, the partnership 
between the voluntary sector and the government took a different form in Canada from that in the U.S. (Shields \& Evans, 1998). In fact, there is a widely held opinion that there really is no "third" sector in Canada, as voluntary social service organizations are viewed as part of the public sector because of the symbiotic nature of the relationship. It is the obligation of governments at all levels to support social services provided by professionals, regardless of the delivery mode, i.e. whether through a branch of government or through a government funded social service agency. This philosophy is only now beginning to unravel in the "name of fiscal restraint and the new competitive global order" (Shields \& Evans, 1998:17). The deep-seated belief in a strong state role in society has been undermined, and has significantly changed the environment in which voluntary social service agencies must exist.

There have been no country wide initiatives in Canada such as the "Learn and Serve America" program, nor has there been the kind of nation-wide calls for the inclusion of community service programs in schools as issued in the U.S. by Goodlad (1984) and Boyer (1983) and the Carnegie Task force on Education of Young Adolescents (1989). Currently, the Ontario Ministry of Education is proposing to make participation in community service mandatory for all high school students in the province of Ontario. The recommendation was made with no systematic evaluation of the impact of community service on either participants or recipients. This study is the first attempt to collect information about the outcomes of adolescent participation in volunteer activities.

\section{Method}

\section{Design}

A quasi-experimental design was used with surveys distributed to experimental and control groups at the beginning of term and at the end of term. The experimental group consisted of those students who participated in the community service program in their school. The control group consisted of students in the same grade, either from the same school, or, in the case of schools where the program was mandatory, from a different, but similar school.

\section{Sample Framework and Limitations}

In 1996, we conducted a survey to ascertain what, if any, educational initiatives were in existence in Toronto's high schools with respect to community service (Meinhard \& Foster, 1998). We found that almost half (46\%) of the 162 respondents representing Toronto's public, separate (Catholic) and private secondary schools had some form of community service programming in which students volunteered their time to the "third sector". However, in $60 \%$ of the schools these programs were generally the result of individual teacher initiatives and included, on average, only $10 \%$ of the student body. In $40 \%$ of the schools the program was mandatory in at least one of the grades.

In this original survey to determine how many of Toronto's secondary schools had community service programs, the response rate was 85\% (Meinhard \& Foster, 1998). Approximately three quarters of the schools that had community service programs indicated that they would be willing to participate in a student survey. Unfortunately, the 1998-1999 school year opened with strikes in the separate (Catholic) schools and work-to-rule slowdowns in the public schools. This had a significant impact on participation rates in our survey. Many schools contacted in May and June 1998, which had agreed to participate in the 
study the following September, were either unavailable because of the strike, or forced to cancel because the work-to-rule orders specifically prevented teachers from participating in extracurricular activities, and many of the community service programs were considered extracurricular. We had considered postponing the student survey till the 1999-2000 school year, but with the new mandatory community service project legislated by the Ontario government coming on line in September 1999, we could not postpone. Thus, our school sample consisted of only 10 schools: three public, two alternative public, three independent, and two separate (Catholic). In total, 467 students participated in the survey: 315 were in the experimental group; and 152 were in the control group. There was a $16.7 \%$ attrition rate making the final sample: 260 experimental; and 129 control.

\section{Survey Instrument}

We obtained permission from the researchers at Brandeis University to adapt or administer as is, the instrument that was used in the Learn and Serve America evaluation. It was based on existing attitudinal scales and questionnaires that were being used in studies of similar programs. Included are scales measuring service experience, educational competence, personal and social responsibility, acceptance of diversity, communication skills, work orientation, engagement in service learning, leadership, formal helping behaviour and self-esteem. The questionnaire was pretested on 233 respondents in May and June, 1998 (Meinhard \& Foster, 1998). Revisions were made to the questionnaire as a result of the pretest

analysis. Some of the questions in the original Brandeis questionnaire were omitted in the final Ontario version because our objectives were narrower.

\section{Data Collection}

The self-administered questionnaire was completed by students using scanner sheets in a classroom setting with a member of the research team supervising. Students were advised that the survey was confidential and that only the researchers would have access to the completed questionnaires. Each student completed two 20 to 30 minute surveys: one at the beginning of term before the community service program started; and one at the end of term.

\section{Analysis}

We used SPSS Version 9 to create the scale scores and analyse the data. We followed the Brandeis method for determining scale scores. Most were an average created from the sum of individual item responses with adjustments made for reverse scoring. Analysis of variance was used for subgroup analysis of the scales. Cross-tabulation and chi-square was used for individual items. The levels of significance reported $(.10, .05$, and .01) were consistent with the Brandeis study to allow comparisons. 


\section{Results and Discussion}

The presentation of findings focuses on identifying the characteristics of community service programs which offer the most positive outcomes for: a) the adolescent participants; and b) the broader community.

\section{Framework}

Because the Ontario study used almost the same questionnaire items as were used in the Brandeis evaluation of the US "Learn and Serve" program, we have the opportunity to compare the community service experiences of Canadian and American high school students.

As mentioned previously, the "Learn and Serve" program is widespread in the US and involves 750,000 school-aged participants. The Brandeis evaluation focuses on a subset of these programs, the upper tier of high quality programs, not a random sample of all programs. In their evaluation, they chose only schoolbased initiatives as opposed to after-school service. The service learning was integrated into an academic course and included some form of structured process for reflection (Melchior, 1997).

The Ontario programs are mostly teacher initiated ad hoc opportunities with no consistency in type of projects available, links to curriculum or requirements for reflection or feedback. These differing environments provide an opportunity to identify program characteristics which are most related to a positive outcome from community service participation.

As Table 1 indicates the Ontario and American programs were quite similar in the types of activities undertaken. A similar percentage was involved in projects which directly helped others (44\% and $43 \%)$. More Canadian students perceived that their projects only indirectly help people (40\% versus $22 \%$ ), whereas Americans were more likely to report their projects as having several objectives (32\% versus $16 \%)$.

Both American and Canadian participants seem equally likely to have conducted their work in teams (31\% and $28 \%$ ) or as an individual assignment (15\% and $12 \%)$. The majority in both countries perceive their projects as having elements of team and individual work (53\% and $60 \%)$.

The major difference between the Ontario and American programs is the opportunity for reflection and feedback. As stated earlier, this was a mandated part of the "Learn and Serve" program in the US, and thus, many participants report opportunities for classroom discussion. In the Ontario programs only a small proportion report the opportunity to discuss their projects during class time (18\%) and even fewer keep a diary of their reflections (12\%).

Table 1: Comparison of Characteristics of the Service Learning Experience By Ontario and American High School Students (percent with this characteristic in their program) 


\begin{tabular}{|l|c|l|}
\hline Reported Characteristics of the Program & $\begin{array}{c}\text { Ontario High School } \\
\text { Students } \\
\text { (n=260) }\end{array}$ & $\begin{array}{l}\text { American High } \\
\text { School Students } \\
\text { (n=435) (a) }\end{array}$ \\
\hline $\begin{array}{l}\text { Service activities were mostly directly helping other } \\
\text { people }\end{array}$ & 44 & 43 \\
\hline $\begin{array}{l}\text { Service activities were mostly indirectly helping other } \\
\text { people }\end{array}$ & 40 & 22 \\
\hline Service activities were both in equal amounts & 16 & 32 \\
\hline Work was conducted as part of a team & 31 & 28 \\
\hline Work was conducted as an individual assignment & 15 & 12 \\
\hline $\begin{array}{l}\text { Work was conducted as a combination of team and } \\
\text { individual }\end{array}$ & 53 & 60 \\
\hline $\begin{array}{l}\text { Kept a journal or diary as part of the community service } \\
\text { project }\end{array}$ & 12 & 74 \\
\hline Project included time to talk in class about experiences & 18 & 76 \\
\hline
\end{tabular}

(a) American data are from: Alan Melchior, National Evaluation of Learn and Serve America, School and Community Based Programs, Interim Report, April 1997, page 12.

Table 2: Comparison of Service Experience By Ontario and American High School Students (percent responding "very often" or "fairly often")

\begin{tabular}{|l|c|l|}
\hline Perceived Characteristics of Service Experience & $\begin{array}{c}\text { Ontario High School } \\
\text { Students } \\
\text { (n=260) }\end{array}$ & $\begin{array}{l}\text { American High } \\
\text { School Students } \\
\text { (n=435) (a) }\end{array}$ \\
\hline Had real responsibilities & 45 & 81 \\
\hline Had challenging tasks & 45 & 59 \\
\hline Made important decisions & 32 & 57 \\
\hline Discussed my experiences with teachers & 10 & 55 \\
\hline Did things myself instead of observing & 44 & 72 \\
\hline Had freedom to develop and use my own ideas & 42 & 68 \\
\hline Discussed my experiences with family and friends & 40 & 64 \\
\hline Had freedom to explore my own interests & 39 & 62 \\
\hline Adults at site took a personal interest in me & 35 & 63 \\
\hline Had a variety of tasks to do at site & 47 & 71 \\
\hline Needed more help from my supervisor & 6 & 10 \\
\hline Adults criticized me or my work & 5 & 6 \\
\hline Felt I made a contribution & 60 & 81 \\
\hline
\end{tabular}

(b) American data are from: Alan Melchior, National Evaluation of Learn and Serve America, School and Community Based Programs, Interim Report, April 1997, page 13.

Table 2 presents the participants' perception of the structure, content and adult support in their community service experience. As the data indicate, the Canadian participants see their service 
experience somewhat differently than do the American participants. The structure of the program in Canada did not appear to provide the same opportunities for the students to have responsibility (45\% versus $81 \%$ ), follow their own interests (45\% versus $62 \%$ ), share their experiences (10\% versus 55\%), or make a contribution $(60 \%$ versus $81 \%)$. The more formally organized and financially supported US programs appeared to offer projects which may have the potential for a more valuable learning experience (Shumer, 1997).

Tables 1 and 2 identified the characteristics of the service experience which differed between the Ontario and US programs. The US program was more likely to provide opportunities for feedback and reflection, for work on projects with real responsibilities, for more freedom in pursuing interests and for making a contribution. The next two tables will explore whether these differences translate into different outcomes for participants.

Table 3 compares social development scale scores for experimental and control groups at posttest for Ontario and American students. While the pattern of significant results is remarkably similar, the reader is cautioned in interpreting these results because of the sampling difficulties with the Canadian data which were described in the Method section. The American data indicate significant improvements in scores on personal and social responsibility, tolerance of diversity, number of helping activities, engagement in school and leadership. The Canadian data indicate significant improvements on all scales except the number of helping activities undertaken. In general, then it appears that regardless of program structure, participants derive some positive benefits from involvement in community service.

Table 3: Comparison of Significant Scale Scores Among Ontario and American High School Students (determined by comparing experimental and control group post-test results)

\begin{tabular}{|l|c|l|}
\hline Social Development Scales & $\begin{array}{c}\text { Ontario High School } \\
\text { Students } \\
\text { (n=260) }\end{array}$ & $\begin{array}{l}\text { American High } \\
\text { School Students } \\
\text { (n=435) (a) }\end{array}$ \\
\hline Personal and social responsibility & +++ & +++ \\
\hline Tolerance of Diversity & +++ & +++ \\
\hline Help & & +++ \\
\hline Engagement in School & +++ & +++ \\
\hline Leadership & +++ & +++ \\
\hline
\end{tabular}

(a) American data are from: Alan Melchior, National Evaluation of Learn and Serve America, School and Community Based Programs, Interim Report, April 1997, page 20.

$+\quad$ differences between the categories were significant at the .10 level

$++\quad$ differences between the categories were significant at the .05 level

$+++\quad$ differences between the categories were significant at the .01 level

Table 4 provides a report of participant assessments of the service experience. Despite no funding, no consistency in the programs and no curriculum requirements in the Ontario program, the levels of satisfaction on many of the items are almost as high as they are for participants in the well-funded and 
standardized American programs. Because the US program included a requirement for the program to be integrated into an academic course, and this was not part of the Ontario program, it is not surprising that the career related learning was so much higher in the US than in Ontario (42\% versus 19\%). While over $80 \%$ of students in both countries feel that students should be encouraged to participate in community service, less than half think it should be mandatory.

Table 4: Comparison of Participant Assessments of Service Experience By Ontario and American High School Students (percent responding to item listed)

\begin{tabular}{|l|c|l|}
\hline Service Experience & $\begin{array}{c}\text { Ontario High School } \\
\text { Students } \\
\text { (n=260) }\end{array}$ & $\begin{array}{l}\text { American High } \\
\text { School Students } \\
\text { (n = 435) (a) }\end{array}$ \\
\hline $\begin{array}{l}\text { Satisfied/very satisfied with community service } \\
\text { experience }\end{array}$ & 83 & 96 \\
\hline $\begin{array}{l}\text { Service performed was helpful/very helpful to } \\
\text { community }\end{array}$ & 84 & 96 \\
\hline $\begin{array}{l}\text { Service performed was helpful/very helpful to individuals } \\
\text { served }\end{array}$ & 88 & 86 \\
\hline Learned a skill that will be useful in the future & 30 & 75 \\
\hline $\begin{array}{l}\text { Learned more or much more during community service } \\
\text { experience than in a typical class taken at school }\end{array}$ & 19 & 42 \\
\hline $\begin{array}{l}\text { Service experience helped me think about the kind of job } \\
\text { or career I might want }\end{array}$ & 84 & 91 \\
\hline $\begin{array}{l}\text { Service experience helped me learn more about a job or } \\
\text { career I might be interested in }\end{array}$ & 42 & 36 \\
\hline $\begin{array}{l}\text { Students should be encouraged to participate in } \\
\text { community service }\end{array}$ & 16 \\
\hline $\begin{array}{l}\text { Students should be required to participate in community } \\
\text { service }\end{array}$ & 83 \\
\hline
\end{tabular}

(b) American data are from: Alan Melchior, National Evaluation of Learn and Serve America, School and Community Based Programs, Interim Report, April 1997, page 32.

Characteristics of programs with the most successful outcomes for participants

A comparison of the characteristics of the community service programs in Canada and the US revealed differences in three key areas:

a) The content and structure of the program. The US program was perceived to provide more opportunities for real responsibility.

b) The level of participant choice and involvement. The US program was perceived to offer more freedom for participants to follow their own interests. 
c) Feedback and reflection. This was a mandated part of the US program, but was not as consistently found in the Ontario program.

The next set of tables focuses on the Ontario results only and explores the characteristics of the program which result in the most positive outcomes for participants.

(a) The content and structure of the program

Table 5 shows the results of an analysis of variance using program content and structure items as the independent variables and the social development scales as the dependent variables.

Working in a team is only marginally significant with just one of the social development indicators, the communication scale. The other items appear to have a more significant impact on social development, particularly when students work on meaningful projects. Having real responsibility, challenging tasks, a variety of tasks and the ability to make decisions have the greatest positive impact on the service experience, communication, number of helping activities and leadership. Owens and Owen (1979) and Shumer (1997) agree that the level of responsibility and the importance of the tasks influence the quality of the learning.

One of the factors that influences this desire for responsibility and challenge is that students view their community service activities with at least the same level of seriousness and commitment with which they view their school work (Meinhard \& Foster, 1999). Indeed, the opportunity for meaningful service may help students who are unhappy in school to stay in school (Moore \& Allen, 1996; Shumar \& Belbas, 1996; Meinhard \& Foster, 1999).

Table 5: Summary of Significant Scale Scores by Content and Structure Characteristics $(\mathrm{n}=260)$

\begin{tabular}{|l|l|l|l|l|l|}
\hline Social Development Scales & $\begin{array}{l}\text { Worked in } \\
\text { a team }\end{array}$ & $\begin{array}{l}\text { Real resp- } \\
\text { onsibilities }\end{array}$ & $\begin{array}{l}\text { Challengin } \\
\text { g tasks }\end{array}$ & $\begin{array}{l}\text { Made } \\
\text { decisions }\end{array}$ & $\begin{array}{l}\text { Variety of } \\
\text { tasks }\end{array}$ \\
\hline Service Experience & & +++ & +++ & +++ & +++ \\
\hline Engagement in Service Learning & & +++ & ++ & +++ & \\
\hline $\begin{array}{l}\text { Personal and Social } \\
\text { Responsibility }\end{array}$ & & +++ & & +++ & ++ \\
\hline Communication & + & +++ & +++ & +++ & ++ \\
\hline Tolerance of Diversity & & +++ & ++ & ++ & \\
\hline Work Orientation & & + & & & ++ \\
\hline Help & & +++ & ++ & ++ & ++ \\
\hline Engagement in School & & + & & & + \\
\hline Leadership & & +++ & +++ & +++ & +++ \\
\hline Self-esteem & & ++ & +++ & & \\
\hline
\end{tabular}

+ differences between the categories were significant at the .10 level

++ differences between the categories were significant at the .05 level 
(c) Level of participant choice and involvement

Table 6 explores whether providing participants with some freedom to make choices enhances the outcome. Having choices at the outset of the experience; that is participating in a truly voluntary not mandatory program and having a key role in designing the nature of the assignment are positively related to engagement in service learning and leadership. Once a participant is involved in a project, having the freedom to explore interests and develop ideas has a significant positive impact on service experience, personal and social responsibility, communication, tolerance of diversity, leadership and self-esteem. Overall, designing programs in which participants take an active role in choosing the type of project on which they are working and are able to maintain involvement in the direction of the project results in significant improvements in several social development measures: service experience, personal and social responsibility, communication tolerance of diversity, leadership and self-esteem. When participants feel that they have made a real contribution to a project, there are significant gains on all measures of social development.

Conrad \& Hedin (1982) and Shumar (1997) also found that student involvement in selecting service experiences enhanced long-term learning. While the trend is toward mandatory programs which by definition limits choice, this may be overcome by including choice components within the mandatory program. Being able to choose from a range of options may provide the flexibility which is associated with enhanced social development improvements (Shumar, 1997).

Table 6: Summary of Significant Scale Scores by Opportunity for Choice and Involvement $(\mathrm{n}=260)$

\begin{tabular}{|l|l|l|l|l|l|l|}
\hline $\begin{array}{l}\text { Social } \\
\text { Development } \\
\text { Scales }\end{array}$ & $\begin{array}{r}\text { Not } \\
\text { required }\end{array}$ & $\begin{array}{l}\text { Did things } \\
\text { myself }\end{array}$ & $\begin{array}{l}\text { Free to } \\
\text { develop } \\
\text { ideas }\end{array}$ & $\begin{array}{l}\text { Free to } \\
\text { explore } \\
\text { interests }\end{array}$ & $\begin{array}{l}\text { Felt } \\
\text { contributed }\end{array}$ & $\begin{array}{l}\text { Designed } \\
\text { service }\end{array}$ \\
\hline $\begin{array}{l}\text { Service } \\
\text { Experience }\end{array}$ & + & +++ & +++ & +++ & +++ & +++ \\
\hline $\begin{array}{l}\text { Engagement in } \\
\text { Service } \\
\text { Learning }\end{array}$ & ++ & + & + & + & +++ & ++ \\
\hline $\begin{array}{l}\text { Personal and } \\
\text { Social } \\
\text { Responsibility }\end{array}$ & & +++ & +++ & +++ & +++ & \\
\hline $\begin{array}{l}\text { Communicatio } \\
\mathrm{n}\end{array}$ & & +++ & +++ & +++ & +++ & \\
\hline $\begin{array}{l}\text { Tolerance of } \\
\text { Diversity }\end{array}$ & & +++ & +++ & +++ & +++ & +++ \\
\hline $\begin{array}{l}\text { Work } \\
\text { Orientation }\end{array}$ & & & + & & +++ & \\
\hline Help & & & + & ++ & +++ & + \\
\hline
\end{tabular}




\begin{tabular}{|l|l|l|l|l|l|l|}
\hline $\begin{array}{l}\text { Engagement in } \\
\text { School }\end{array}$ & & & & & +++ & \\
\hline Leadership & ++ & +++ & +++ & +++ & +++ & +++ \\
\hline Self-esteem & & +++ & +++ & +++ & +++ & + \\
\hline
\end{tabular}

$+\quad$ differences between the categories were significant at the .10 level

$++\quad$ differences between the categories were significant at the .05 level

$+++\quad$ differences between the categories were significant at the .01 level

(d) Feedback and reflection

As mentioned previously, the US program was designed with mandatory feedback and reflection processes, whereas this was not a feature of the Ontario program. The results in Table 7 confirm the soundness of the US strategy. Keeping a journal is probably more influential in improving social development than is having time to talk in class or discussing the experience with teachers. These results are consistent with the findings of Conrad and Hedin (1982), Rutter and Newman (1989), Shumer and Belbas (1996) and Shumer (1997). Interestingly, the data suggest that discussions held with family and friends are even more important in effecting improvements in social development than are the structured processes such as keeping a journal and time to talk in class developed as part of the program. This finding underlines the importance of parental involvement in enhancing the success of such initiatives.

Table 7: Summary of Significant Scale Scores by Feedback Opportunities $(\mathrm{n}=260)$

\begin{tabular}{|l|c|l|l|l|}
\hline Social Development Scales & $\begin{array}{l}\text { Kept a } \\
\text { journal }\end{array}$ & $\begin{array}{l}\text { Time to talk } \\
\text { in class }\end{array}$ & $\begin{array}{l}\text { Discuss with } \\
\text { teachers }\end{array}$ & $\begin{array}{l}\text { Discuss with } \\
\text { family }\end{array}$ \\
\hline Service Experience & ++ & ++ & +++ & +++ \\
\hline Engagement in Service Learning & ++ & & & +++ \\
\hline Personal and Social Responsibility & ++ & ++ & + & \\
\hline Communication & & & & ++ \\
\hline Tolerance of Diversity & & & & + \\
\hline Work Orientation & & & & ++ \\
\hline Help & ++ & & & + \\
\hline Engagement in School & & & ++ & ++ \\
\hline Leadership & +++ & ++ & & \\
\hline Self-esteem & & & & \\
\hline
\end{tabular}

$+\quad$ differences between the categories were significant at the .10 level

$++\quad$ differences between the categories were significant at the .05 level

$+++\quad$ differences between the categories were significant at the .01 level

(e) Role of adults

Although our comparative analysis did not reveal any differences between Ontario and American students in their assessment of the role and involvement of adults, we wanted to explore this issue further. Besides 
teachers and parents, adults at the project site can potentially influence the outcome of this experience for participants. The findings in Table 8 reveal the significant role played by adults at the voluntary agency. If an adult at the site is interested in the student, the service experience, engagement in service learning, personal and social responsibility, communication, tolerance of diversity, number of helping activities, engagement in school, leadership and self-esteem are all significantly enhanced. This is consistent with the review of service learning research conducted by Shumar (1997). Interestingly, the positive impact on social development is evident even if the participant's interaction with the adult is only to be criticized.

Table 8: Summary of Significant Scale Scores by Role of Adults $(\mathrm{n}=260)$

\begin{tabular}{|l|c|l|l|}
\hline Social Development Scales & $\begin{array}{c}\text { Adult at site } \\
\text { interested in me }\end{array}$ & $\begin{array}{l}\text { Needed help from } \\
\text { supervisor }\end{array}$ & $\begin{array}{l}\text { Adult criticized me } \\
\text { or my work }\end{array}$ \\
\hline Service Experience & +++ & & ++ \\
\hline Engagement in Service Learning & ++ & & + \\
\hline Personal and Social Responsibility & +++ & + & +++ \\
\hline Communication & +++ & ++ & +++ \\
\hline Tolerance of Diversity & +++ & ++ & +++ \\
\hline Work Orientation & + & ++ & +++ \\
\hline Help & ++ & & \\
\hline Engagement in School & ++ & +++ & +++ \\
\hline Leadership & +++ & ++ & ++ \\
\hline Self-esteem & ++ & ++ & ++ \\
\hline
\end{tabular}

$+\quad$ differences between the categories were significant at the .10 level

$++\quad$ differences between the categories were significant at the .05 level

$+++\quad$ differences between the categories were significant at the .01 level

Unfortunately, the role of adults in the Ontario program was mostly "hands off". Slightly more than onethird felt the adults at the volunteer site took a real interest in them. Few felt they needed help from their adult supervisor $(6 \%)$, and even fewer $(5 \%)$ felt the adults criticized their work. The impact of this role or non-role of adults in this experience is evidenced by the significant negative shift from pretest to posttest in perception of the supportiveness of adults for student efforts to work on community problems. In the pretest only $20 \%$ of students perceived adults as not supportive, whereas at the posttest the proportion had increased significantly to $30 \%$ (p<.009) (Meinhard \& Foster, 1999).

\section{(f) Predisposing factors}

Up to now the analysis has focused on identifying those features of the community service program that significantly increase the positive impact of participation on the social development of participants. This section of the analysis will focus on predisposing factors already in existence which may enhance the effect of program participation for one subgroup over another.

As Table 9 indicates, females seem to derive more positive outcomes from the community service experience than do males. They scored significantly higher on engagement in service learning, personal and social responsibility, tolerance of diversity and leadership. At the pre-test stage, females had 
marginally higher scores on personal and social development, tolerance of diversity and engagement in school.

As previous research has indicated, the impact of familial role models on propensity to volunteer and deriving a positive experience from volunteering cannot be underestimated (Sundeen \& Raskoff, 1994; Hodgkinson \& Weitzman, 1996; Buchel \& Duncan, 1998). On all scales but three. participants whose parents were regular volunteers had more positive scale scores than those whose parents did not volunteer on a regular basis. At the pretest stage, participants with parents who volunteer scored marginally higher on personal and social responsibility, communication and leadership. These results suggest that the community service experience, not the predisposing factors, was responsible for the enhanced social development scores at the time of the posttest.

Table 9: Summary of Significant Scale Scores by Participant Subgroups $(\mathrm{n}=260)$

\begin{tabular}{|l|c|l|l|l|}
\hline \multirow{2}{*}{ Social Development Scales } & \multicolumn{2}{|c|}{ Females (a) } & \multicolumn{2}{l|}{ Parents Volunteer (b) } \\
\cline { 2 - 5 } & Pre-Test & Post-Test & Pre-Test & Post-Test \\
\hline Service experience & NA & & NA & +++ \\
\hline Engagement in Service Learning & NA & ++ & NA & +++ \\
\hline Personal and Social Responsibility & + & +++ & + & +++ \\
\hline Communication & & & + & \\
\hline Tolerance of Diversity & + & +++ & & ++ \\
\hline Work Orientation & & & & \\
\hline Help & & & & + \\
\hline Engagement in School & + & & & \\
\hline Leadership & & + & + & +++ \\
\hline Self-Esteem & & & & + \\
\hline
\end{tabular}

$+\quad$ differences between the categories were significant at the .10 level

$++\quad$ differences between the categories were significant at the .05 level

$+++\quad$ differences between the categories were significant at the .01 level 


\section{Characteristics of programs with the most successful outcomes for the community}

In addition to an impact on the social development of high school students, participating in community service programs will hopefully be the foundation for a lifelong commitment to volunteering. More than half of respondents when asked (54\%) responded that they had done additional volunteering.

Table 10 lists the program characteristics which have significantly influenced participants to engage in additional volunteering. The previous analysis had identified these factors as essential for enhancing the social development of participants; namely, designing a program with real responsibilities and challenges, giving participants choice about the design of their assignment and involvement with the direction it takes, providing feedback and reflection opportunities, not only at school but also with family, and ensuring adults at the voluntary organization are committed to and involved with the participants. These same characteristics are related to a higher likelihood of volunteering.

Table 10: Impact of Program Characteristics on Propensity of Volunteer in the Future $(\mathrm{n}=260)$

\begin{tabular}{|c|c|}
\hline Program Characteristic & $\begin{array}{l}\text { Significantly More Likely to Have Done } \\
\text { Additional Volunteering }\end{array}$ \\
\hline $\begin{array}{c}\text { Content and Structure Characteristics } \\
\text { Had real responsibilities } \\
\text { Had a variety of tasks }\end{array}$ & $\begin{array}{l}+++ \\
+++\end{array}$ \\
\hline $\begin{array}{l}\text { Involvement and Choice Characteristics } \\
\text { Free to develop own ideas } \\
\text { Free to explore interests } \\
\text { Felt contributed } \\
\text { Designed service myself }\end{array}$ & $\begin{array}{c}++ \\
++ \\
+++ \\
++\end{array}$ \\
\hline $\begin{array}{l}\text { Feedback Opportunities } \\
\text { Kept a journal } \\
\text { Discussed service with family and friends }\end{array}$ & $\begin{array}{c}+++ \\
++\end{array}$ \\
\hline $\begin{array}{l}\text { Role of Adults } \\
\text { Adult at the site interested in me } \\
\text { Needed help from my supervisor } \\
\text { Adult criticized me or my work }\end{array}$ & $\begin{array}{l}+++ \\
+++ \\
+++\end{array}$ \\
\hline $\begin{array}{ll}+ & \text { differences between the categories were signif } \\
++ & \text { differences between the categories were signif } \\
+++ & \text { differences between the categories were signif }\end{array}$ & $\begin{array}{l}\text { e.10 level } \\
\text { e.05 level } \\
\text { e.01 level }\end{array}$ \\
\hline
\end{tabular}

\section{Conclusion}

The purpose of this paper has been to identify the characteristics of community service programs which result in the most significant positive gains for the participants in terms of social development and for the community in terms of the next generation of volunteers. The results of the Ontario study suggest that the 
same characteristics that enhance the positive outcomes for participants also increase the likelihood of the community benefiting through an increased propensity to volunteer. These features include:

(a) Choosing projects and programs in which participants have meaningful work. Participants want real responsibility, challenging tasks and a variety of activities.

(b) Designing projects and programs so that participants have significant input. This serves to increase involvement and commitment and ultimately satisfaction and the positive impacts of participation on social development.

(c) Incorporating structured opportunities for feedback and reflection. This includes in-class processes in addition to discussions with family and friends about their experiences.

(d) Ensuring committed and adequate on-site adult supervision. Adult support enhances improvement in social development and commitment to future volunteering.

Whether a program is mandatory or not, and whether a participant works in a team or as an individual do not seem to be as important determining factors of social development or commitment to community service as are the other structural features.

In addition, the results of this study indicate that voluntary organizations have a key role to play in the successful outcome of community service experience. They determine whether the student does meaningful work, the quality of the adult supervision, and the level of input participants have in the project. The Ministry of Education only has control over whether the project involves a formal reflection and feedback component and the range of choice a student has in picking a specific project in which to fulfill the community service requirement for graduation.

It is therefore somewhat concerning that the design of the program in Ontario involves no formal partnerships or dialogue with the voluntary sector organizations who will be responsible for providing and supervising these placements. Instead, the Ministry is leaving it up to individual students to make their own arrangements for meeting their forty hour community service requirement.

Representatives of voluntary organizations, particularly volunteer centres whose job it is to match volunteers to appropriate organizations are worried that they will not be prepared for the influx of students seeking community service experience, and more importantly, that they will be unable to provide meaningful volunteer opportunities. As the data clearly show, unless placements are well planned, the experience will not result in the positive social development and commitment to community service that is desired.

\section{References}

Barber, B. (1992). An Aristocracy of Everyone. New York: Ballantine.

Bellah, R., Madsen, R., Sullivan, W., Swidler, A. \& Tipton, S. (1985). Habits of the Heart. Berkeley: University of California Press.

Boyer, E. (1983). High School. New York: Harper and Row. 
Buchel, F. \& Duncan, G.J. (1998). Do parents' social activities promote children's school attainments? Evidence from the German socio-economic panel. Journal of Marriage and the Family, 60(1): 95-108.

Carnegie Task Force on Education of young Adolescents. (1989). Turning Points: Preparing American youth for the 21 st century. New York: Carnegie Council on Adolescent Development of the Carnegie Corporation.

Cnaan, R., Kasternakis, A. \& Wineburg, R.J. (1993). Religious people, religious congregations, and volunteerism in human services: Is there a link? Nonprofit and Voluntary Sector Quarterly, 22(1): 33-51.

Conrad, D. \& Hedin, D. (1982). The impact of experiential education on adolescent development. Child and Youth Services, 3: 57-76.

de Schweinitz, K. (1943). England's Road to Social Security. New York: Barnes.

Feingold, Mordechai (1987). Philanthropy, pomp and patronage: Historical reflections upon the endowment of culture. Daedalus, 116(1): 155-178.

Foster, M. \& Meinhard, A. (1996). Toward Transforming Social Service Organizations in Ontario. Presented at Babson Conference on Entrepreneurship, Seattle, WA.

Goodlad, J. (1984) A Place Called School. New York: McGraw-Hill.

Hall, M. \& Banting, K.G. (2000). The nonprofit sector in Canada: An Introduction. In K.G. Banting (Ed.), The nonprofit sector in Canada. Montreal and Kingston: School of Policy Studies, Queen's University.

Hodgkinson, V.A. \& Weitzman, M.S. (1996). Volunteering and giving among American teenagers 12 to 17 years of age. Washington DC: Independent Sector.

Independent Sector. (1990). Volunteering and Giving Among American Teenagers 14 to 17 Years of Age: Findings from a National Survey. Independent Sector, Washington, DC.

Kraft, Richard (1996). Service learning: An introduction to its theory, practice and effects. Education and Urban Society, 28(2): 131-159.

Lefebvre, B. (1996). From minutes of the Standing Committee on General Government, Government of Ontario. Timmins Ont.: June 16, 1996.

Meinhard, A. \& Foster, M. (1997). Responses of Women's Voluntary Organizations to the Changing Social, Political and Economic Environment. Presented at the 26th Annual ARNOVA Conference, Indianapolis, IN.

Meinhard A. \& Foster, M. (1998). Community Service Programs in Toronto Secondary Schools. Presented at the $27^{\text {th }}$ Annual ARNOVA Conference, Seattle, WA. 
Meinhard A. \& Foster, M. (1999). The Impact of Volunteer Community Service Programs on Students in Toronto's Secondary Schools. Presented at the $28^{\text {th }}$ ARNOVA Conference, Washington, DC.

Melchior, A. (1997). National Evaluation of Learn and Serve America School and Community-Based Programs: Interim Report. Unpublished Manuscript.

Moore, C.W. \& Allen, J.P. (1996). The effects of volunteering on the young volunteer. The Journal of Primary Prevention, 17(2): 231-258.

Newman, F.M. \& Rutter, R.A. (1986). Profile of high school community service programs. Educational Leadership, 43(4): 65-71.

Owens T. \& Owen, S. (1979). Enhancing the quality of community learning experiences. Alternative Higher Education: The Journal of Non-traditional Studies, 4(2): 103-112.

Prudential. (1995). Prudential Spirit of Community Initiative: Highlights of the Youth Survey of Community Involvement.[Online] (click here)

Putnam, R. (1993). Making democracy work: Civic traditions in modern Italy. Princeton NJ: Princeton University Press.

Putnam, R.D. (1995). Bowling alone: America's declining social capital. Journal of Democracy, 6(1): 6578.

Raskoff, S., \& Sundeen, R. (1998). Youth socialization and civic participation: The role of secondary schools in promoting community service in southern California. Nonprofit and Voluntary Sector Quarterly, 27(1): 66-87.

Rutter, R. \& Newman, F. (1989). The potential of community service to enhance civic responsibility. Social Education, 53(6): 371-74.

Salamon, Lester M. \& Anheier, Helmut K. (1996). The Emerging Nonprofit Sector: An Overview. Manchester: Manchester University Press.

Shumer, R. (1997). What research tells us about designing community service programs. National Association of Secondary School Principals Bulletin, 81(591): 18-24.

Shumer, R. \& Belbas, B. (1996). What we know about service learning. Education and Urban Society, 28(2): 208-223.

Stewart, W. (1996). The Charity Game: Waste and Fraud in Canada's \$86-Billion-a-Year Compassion Industry. Toronto: Douglas \& McIntyre.

Sundeen, R. \& Raskoff, S. (1994). Volunteering among teenagers in the United States. Nonprofit and Voluntary Sector Quarterly, 23(4): 383-403. 
Tucker, D.J., Singh, J.V. \& Meinhard, A.G. (1990). Organizational form, population dynamics and institutional change: A study of birth patterns of voluntary organizations. Academy of Management Journal, 33:151-178.

Weinrich, P. (1996). The Third Sector. (click here)

Wuthnow, R. (1991). Acts of Compassion: Caring for Others and Helping Ourselves. Princeton, NJ: Princeton University Press. 